\title{
FOUR RELIQUARY BUSTS FROM THE FORMER MONASTERY OF MADRE DE DEUS: STUDY AND CONSERVATION
}

\author{
Diana Cunha ${ }^{1}$, Carolina Barata ${ }^{2}$, Alexandre Pais ${ }^{1}$ \\ ${ }^{1}$ Research Centre for Science and Techonology of the Arts (CITAR), School of Arts, \\ Portuguese Catholic University, Porto, Portugal \\ ${ }^{2}$ Research Centre for Science and Techonology of the Arts (CITAR), School of Arts, \\ Portuguese Catholic University, Porto, Portugal/GEOBIOTHEC, GeoBiosciences, \\ GeoTechnologies and GeoEngineering, University of Aveiro, Portugal
}

\begin{abstract}
This article describes the conservation and restoration treatments as well as the historical and analytical study carried out on four reliquary busts from the former Monastery of Madre de Deus, in Lisbon, currently the National Azulejo Museum. These reliquaries belong to a collection composed of forty-five reliquary busts, which represent a unique and practically intact set and has dated busts from the late $16^{\text {th }}$ century until late $17^{\text {th }}$ century. The analytical results obtained suggest that the four busts were produced according to the art treatises of the time and the identified materials meet the materials that would be used in that period.
\end{abstract}

\section{Keywords}

Polychrome Sculpture, Baroque, Monastery of Madre de Deus, Reliquary Busts, Conservation and Restoration, Analytical Study.

\section{Quatro Bustos-relicários do Mosteiro da Madre de Deus: Estudo e Conservação}

\section{Resumo}

O presente artigo descreve os tratamentos de conservação e o estudo histórico e analítico realizado sobre quatro bustos-relicários pertencentes ao Mosteiro da Madre de Deus, em Lisboa, atualmente o Museu Nacional do Azulejo. Estes relicários pertencem a uma coleção composta por quarenta e cinco bustos-relicários, que representa um conjunto praticamente íntegro e único, e que contém bustos datados desde finais do século dezasseis até finais do século dezassete. Os resultados do estudo analítico sugerem que os quatro bustos terão sido produzidos de acordo com os tratados artísticos da época de produção, e os materiais identificados vão ao encontro dos que seriam utilizados naquele período.

Palavras-chave: Escultura Policromada, Barroco, Mosteiro da Madre de Deus, Bustosrelicários, Conservação e Restauro, Estudo analítico. 


\section{Cuatro Bustos-relicario del Monasterio de la Madre de Dios: Estudio y Conservación}

\section{Resumen}

El presente artículo describe los tratamientos de conservación y el estudio histórico y analítico realizados sobre cuatro bustos-relicario pertenecientes al Monasterio de la Madre de Dios, en Lisboa, actualmente Museo Nacional del Azulejo. Estas piezas pertenecen a una colección compuesta por cuarenta y cinco bustos-relicario, conjunto prácticamente íntegro y único, y que contiene bustos datados desde finales del siglo dieciséis hasta finales del siglo diecisiete. Los resultados del estudio analítico sugieren que los cuatro bustos habrían sido realizados de acuerdo con los tratados artísticos de la época de producción y los materiales identificados en ellos coinciden con los utilizados en aquel período.

\section{Palabras clave}

Escultura polícroma, Barroco, Monasterio de la Madre de Dios, Bustos-relicario, Conservación y Restauración, Estudio analítico.

\section{Introduction}

The Monastery of Madre de Deus was founded in 1509 by Queen Leonor of Braganza, King John II's wife, reflecting the late Gothic style of that time. Currently, it is one of the most important remaining monasteries in the city of Lisbon, classified as national monument. Furthermore, the building houses the facilities of the National Azulejo Museum, installed there since 1965.

The Queen was a great collector of art and at the time of her death (1525), the Monastery of Madre de Deus was full of works of art from Northern and Southern Europe, and from the East, "witnessing the manifestly multifaceted taste of the Queen" (CURVELO, 2009). Included in this art repository is the set of reliquary busts that was collected over the years (TELLES, 1899).

This study focuses on four reliquary busts: Saint Agatha (Figure 1), Saint Lawrence (Figure 1), Innocent Saint (Figure 2), and Franciscan Saint (Figure 2). These pieces were selected together with the curators of the National Azulejo Museum according to criteria related to the pressing need of their intervention, as well as the interest of their study.

The desire and inherent interest to develop this study were not only due to the artistic quality of these pieces and the fact that they belong to one of the few groups in Portugal that remain almost intact but also because there is little information about them, making it even more interesting and challenging to study.

The main results of the historical and analytical research and of the conservation treatment that have been undertaken are presented in this article.

\section{The Four Reliquary Busts from Madre de Deus}

The four reliquary busts came from the baroque reliquary cabinet located in the high choir of the church of Madre de Deus (Figure 3) and belong to a group of forty-five reliquary busts, most of them currently in the Museum's storage. The collection of reliquary busts of Madre de Deus can be divided into six categories: the Innocent saints, holy bishops, Franciscan saints, virgin martyrs, martyrs, and holy popes ${ }^{1}$.

${ }^{1}$ Dr. Alexandre Pais, from the National Azulejo Museum, provided this information. 

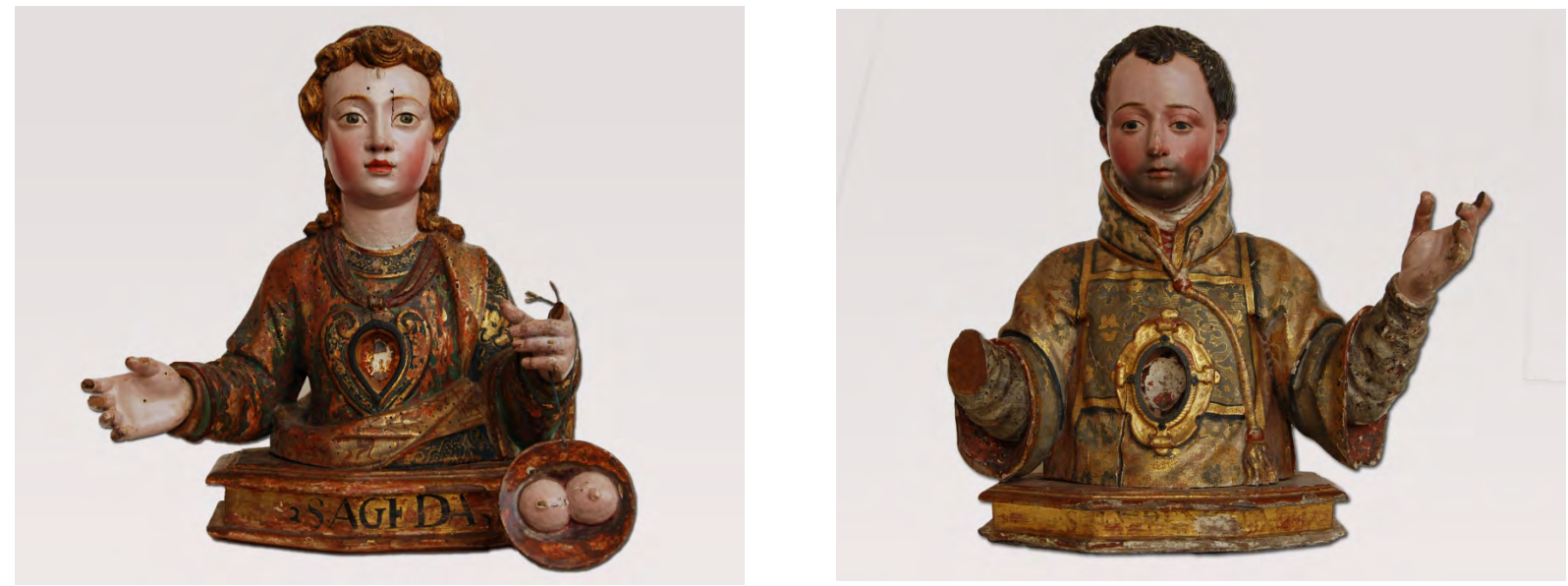

Figure 1 - Reliquary busts of Saint Agatha and Saint Lawrence before the conservation treatment.

The four selected pieces belonged to the groups of the virgin martyrs (Saint Agatha), martyrs (Saint Lawrence), the Innocent saints (Innocent Saint), and the Franciscan saints (Franciscan Saint). The last two could not be identified, having been awarded the designation of the category to which they belong.
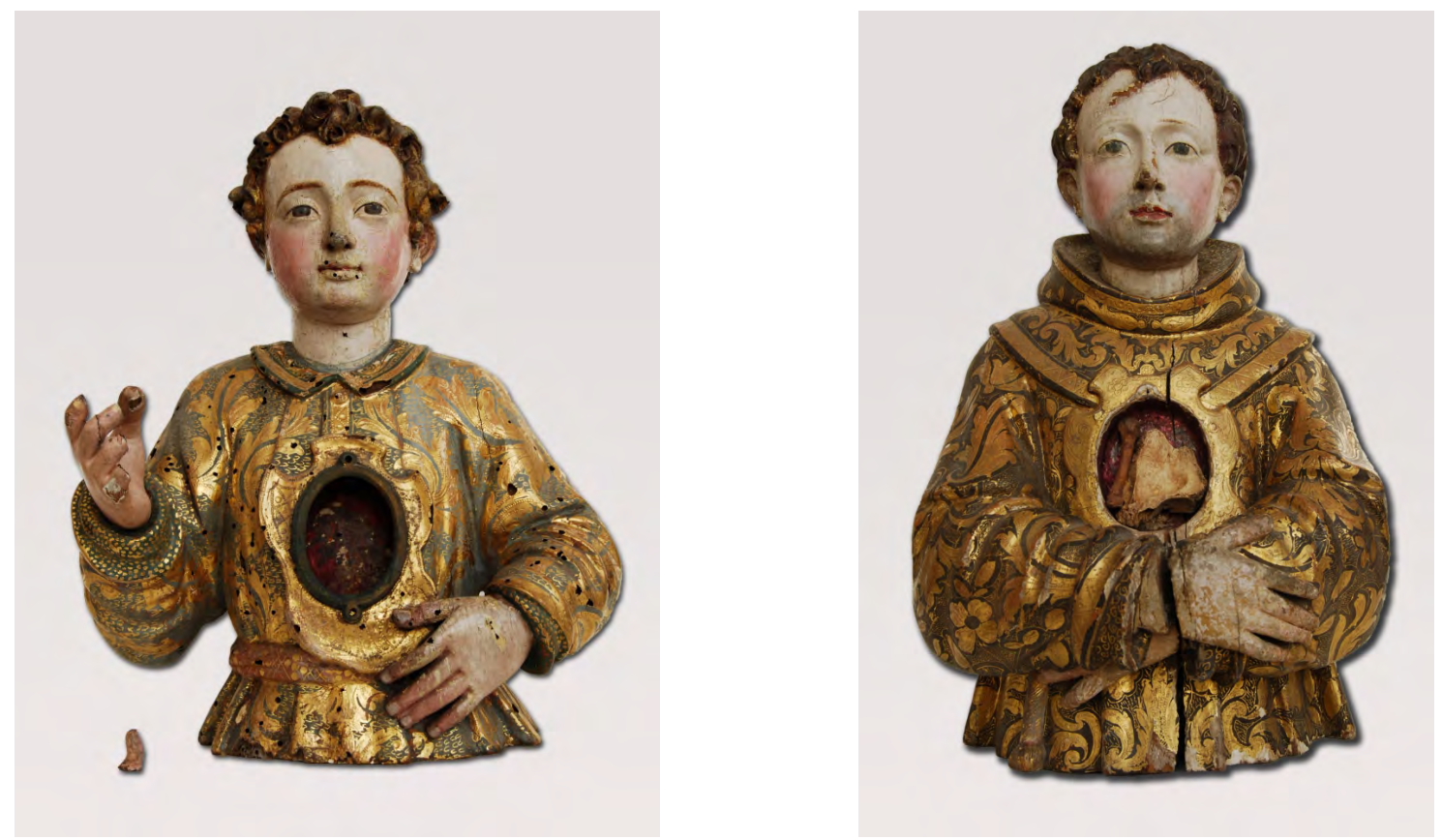

Figure 2 - Reliquary bust of Innocent Saint and Franciscan Saint before the conservation treatment.

The workshop of these sculptures is not known: they might have been produced in Portugal specifically for the Monastery, acquired or even offered. Although she had passed away when these objects came to the Monastery, the Queen's proximity with other European courts would facilitate the acquisition of this kind of works abroad. In fact, there are records of reliquaries offered to the Queen and it is known that the number of works of art from other European countries donated to the Monastery of Madre de Deus is large (CURVELO, 2009, DIAS, 1987). Based on their stylistic features and on the analytical results obtained, these four busts were framed in the Portuguese Baroque period (BRITO \& MORNA, 2000), despite the fact that two of them still denote Mannerist influence (early $17^{\text {th }}$ century), namely the busts of Saint Agatha and Saint Lawrence (DIAS, 1995). 


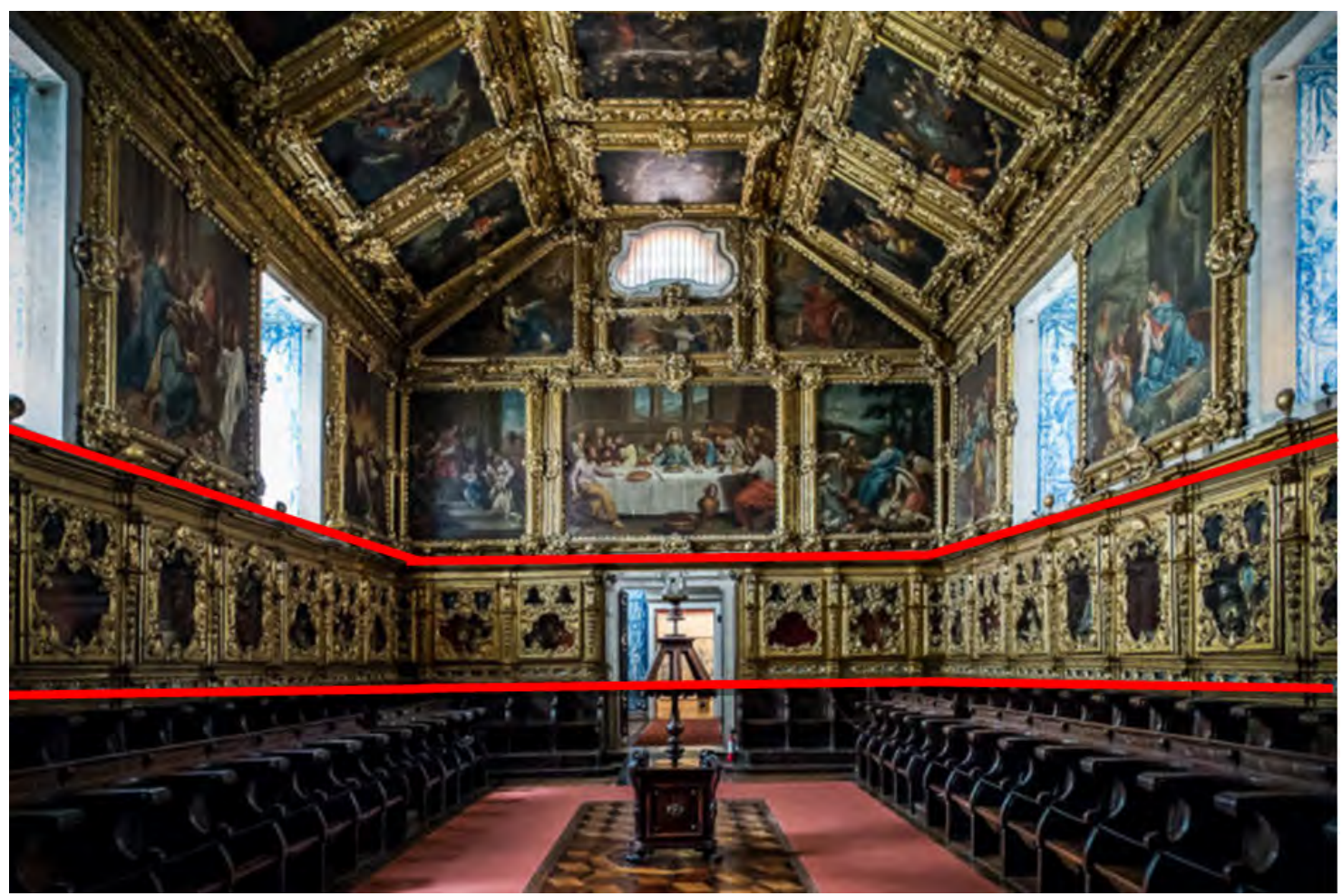

Figure 3 - The baroque reliquary cabinet from the high choir of the Church of Madre de Deus.

\section{Conservation Treatment}

In general, at the support level, the sculptures were in a regular conservation condition, excepting the Innocent Saint, which was in a lesser state of conservation. The main pathologies that the wooden supports presented included lacunae, cracks, fissures, and spacing between the different elements of construction, caused by the dimensional variations of the wood as a result of the oscillations of relative humidity and temperature.

Concerning the polychrome surface, all the busts were in a poor conservation condition. There were pathologies such as lacunae, accumulated surface dirt resulting from improper storage, as they shouldn't have been duly protected from dust and dirt, detachments caused by the dimensional variations of the wood and bleaching caused by old cleaning attempts with chemical solutions which should have solubilized part of the chromatic layer's binder (VIVANCOS RAMÓN, 2007).

\section{Intervention Criteria}

In the conservation and restoration treatment of the four busts, not only an eminently conservative action was aimed, but also to restore the aesthetic features of the works, as they still fulfil their original function of worship. For that reason, the chromatic reintegration was included into the intervention proposal.

Regarding the methodology, the criteria of respect for both the original materials and historicity was followed, as well as compatibility and reversibility: compatibility of the intervention materials with those of the sculptures; reversibility of the treatments performed; compatibility of these treatments with future interventions (VICENTE RABANAQUE, 2015). Cleaning is an irreversible treatment and, for that reason, it was previously established which were the limits to achieve, what was meant to be removed and why (DÍAZ MARTÍNEZ 
\& GARCÍA ALONSO, 2011). Regarding restoring the aesthetic feature, the fundamentals of Cesare Brandi were adopted, stating that the reintegration must be invisible at the distance from which the work is expected to be seen, but immediately recognizable to the naked eye as soon as people get a closer approach (BRANDI, 2006). Finally, about the lack of some elements, such as the Saint Lawrence right hand and the others figures' fingers, it was decided not to rebuild them due to the lack of known documentation that witnesses its forms and original positions.

\section{Treatments Performed}

Before any other step, and since the polychrome surface was in severe detachment, the first treatment performed was to fix the polychrome layer with fish glue (Figure 4). After the stabilization of the surface, the wooden support stabilization could have been started.

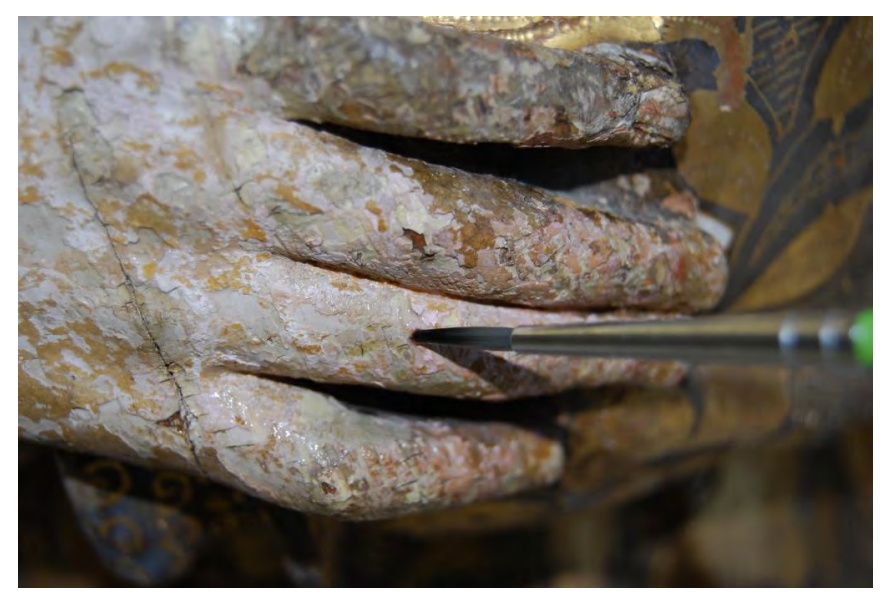

Figure 4 - Franciscan Saint: Fixing the polychrome layer with fish glue.

Firstly, a mechanical cleaning was made using a vacuum cleaner and soft brushes, followed by a preventive disinfestation with a gelled solution of permethrins and aliphatic hydrocarbon solvents (Xilix® gel) (VIVANCOS RAMÓN \& PEREZ MARIN, 2002). The wooden support was consolidated with an acrylic resin dissolved in an aromatic organic solvent (Paraloid $\mathbb{R}$ B-72 in Shellsol ${ }^{\circledR}$ A). Likewise, the relics of Saint Agatha were consolidated with the same material since they were in a state of powderiness and, thereafter, the four fragments were glued with rabbit glue. The placement of the relics in their reliquaries was also performed with rabbit glue and the glass of the reliquary of Saint Agatha, which was fractured in two halves, was glued with cyanoacrylate adhesive. Furthermore, some of the support elements, such as Saint Agatha's both hands and the Innocent Saint right hand, were glued with a neutral adhesive of ethyl vinyl acetate (Evacon-R $\otimes$ ). The cracks and fissures of the support were filled with an inert low-density wood (balsa), glued with Evacon- $R \circledast$, as they enhance the degradation by facilitating the penetration of dirt, moisture, and the entry of insects (CALVO, 1997). For the same reasons, the holes caused by insect attacks were filled

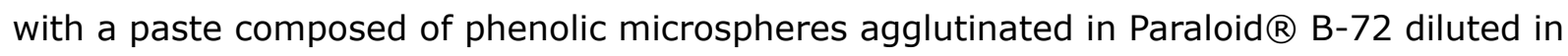
Shellsol $®$ A (Figure 5). Lastly, the metallic elements were cleaned and stabilized with tannic acid for the iron elements and a cleansing gel for the copper elements. 


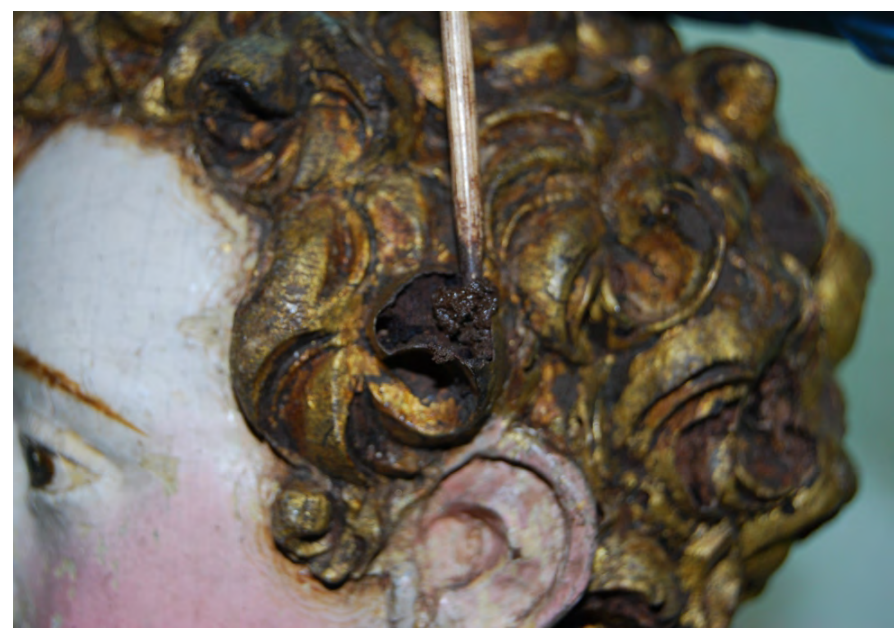

Figure 5 - Innocent Saint: Filling the holes of the insect attack with a paste composed of phenolic microspheres and Paraloid $\mathbb{B}$ B-72.

Concerning the polychrome surface, besides the fixation of the detached fragments, a mechanical cleaning was carried to remove dirt and loose dust, as well as a wet cleaning in order to remove adhering dirt and oxidized varnish films. Adhering dirt was removed using aqueous solutions and previous varnish films were cleared with solvent solutions. After cleaning the surfaces, the exposed white ground layers, which disturbed the correct perception of the sculptures, were dyed with a brown vegetable dye (vieux chêne) so that the tonality approaches the tone of the wooden support. The next step was the application of a Paraloid $\AA$ B-72 varnish (at a concentration of $3 \%$ ) dissolved with Shellsol $\AA A$, as an isolation film before filling some of the lacunae. Lacunae filling was performed in the flesh tones areas only, with a paste composed of calcium carbonate, lithopone, and rabbit glue (Figure 8). After that, the paste was polished and chromatically reintegrated with pigments agglutinated in gum Arabic (Figure 6).
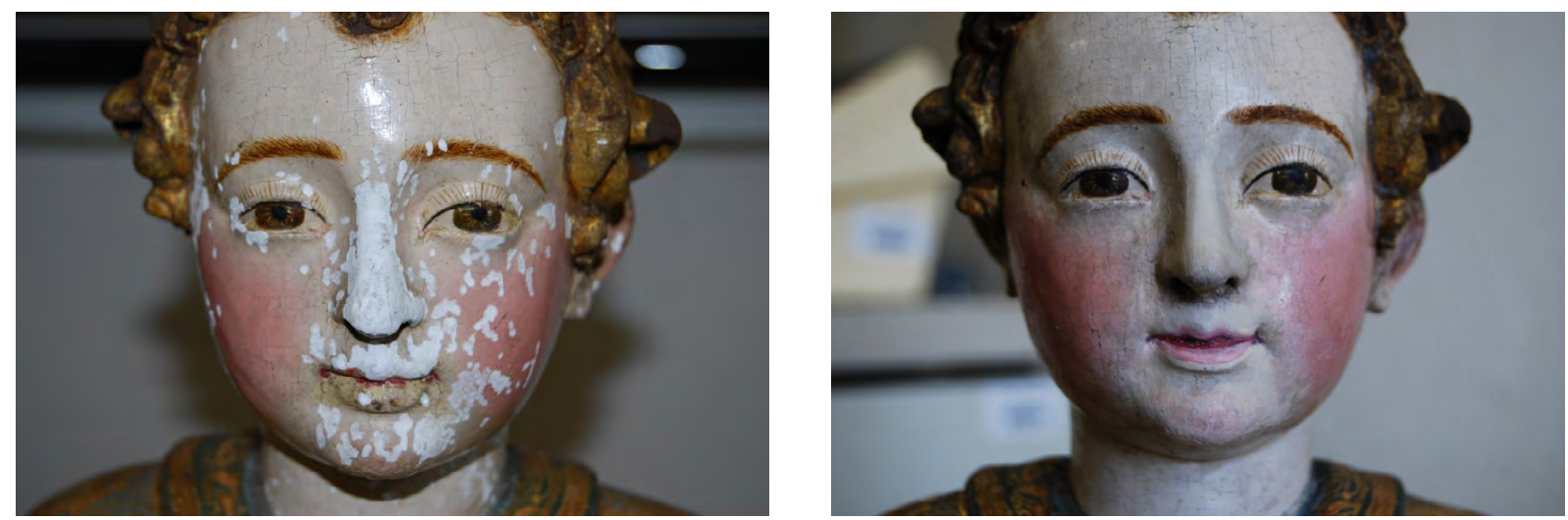

Figure 6 - Innocent Saint's face during the filling lacunae procedure and after the chromatic reintegration.

Finally, to protect the surfaces from dust and dirt, and to unify the appearance of the chromatic reintegration with the remaining polychrome, a final protective film of Paraloid $\mathbb{R}$ B-72 was applied. 


\section{Analytical Study}

Sixteen samples were taken from the polychrome surface (Figure 7) of the sculptures and were mounted in a semitransparent synthetic resin (Mekton ${ }^{\circledR} 20$ Powder blended in Mekton (C20 Liquid) and prepared as cross-sections. First, to study the stratigraphy of the samples, they were examined by optical microscopy at different magnifications (100x and 200x) with an Olympus BX41 optical microscope equipped with an attached ProgRes ${ }^{\circledR}$ C5 digital camera, with reflected light and polarized in dark field. The thickness of each layer and their characteristics such as colour, size, and shape of the constituent particles were identified. Using the microphotographic records obtained, the number of layers were numbered in the same order in which they were applied.

Scanning electron microscopy with energy dispersive X-ray spectrometry (SEM-EDS) was used to identify the elemental composition of the constituent materials and to identify its distribution. Samples were carbon coated by vaporization and analysed with a Hitachi SU-70 FE-SEM microscope with an EDS detector. The magnification used was of 200x and a tension of $20 \mathrm{kV}$. This technique allows both analyses of specific elementary points and semi-quantitative evaluations (LE GAC et al., 2009). Representative samples collected from the flesh and polychrome areas were analysed - equivalent to two samples per sculpture. Some samples were analysed by Fourier transform infrared spectroscopy ( $\mu$-FTIR) to ascertain the classes of organic compounds used, such as binders. The preparation of the samples for $\mu$-FTIR included the separation of each layer, using a binocular microscope, so that they could be individually analysed, and it was used a Thermo Nicolet infrared microscope coupled to a Thermo Nicolet Nexus 670 FTIR IR spectrometer.

Lastly, microchemical tests with fuchsine were carried over the cross-sections with the objective of ascertaining the presence of protein binders.
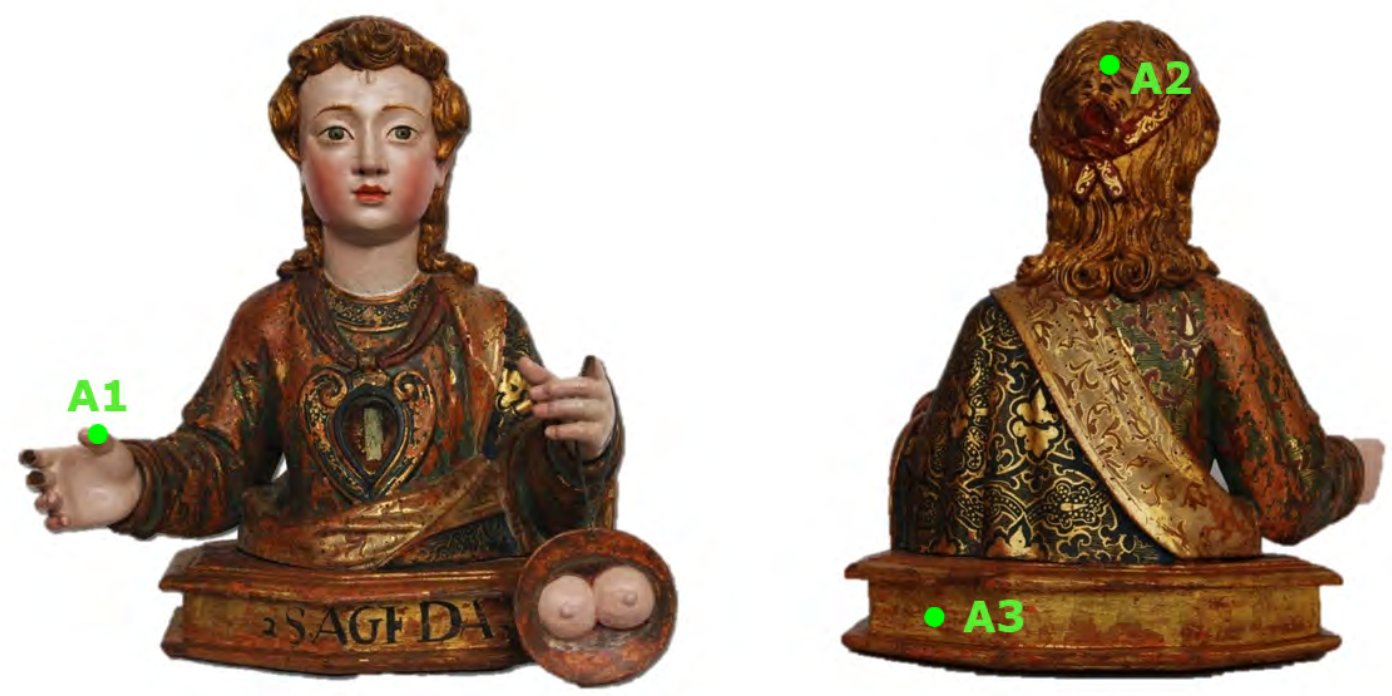

Figure 7 - Scheme from where samples were taken for the analytical study. 

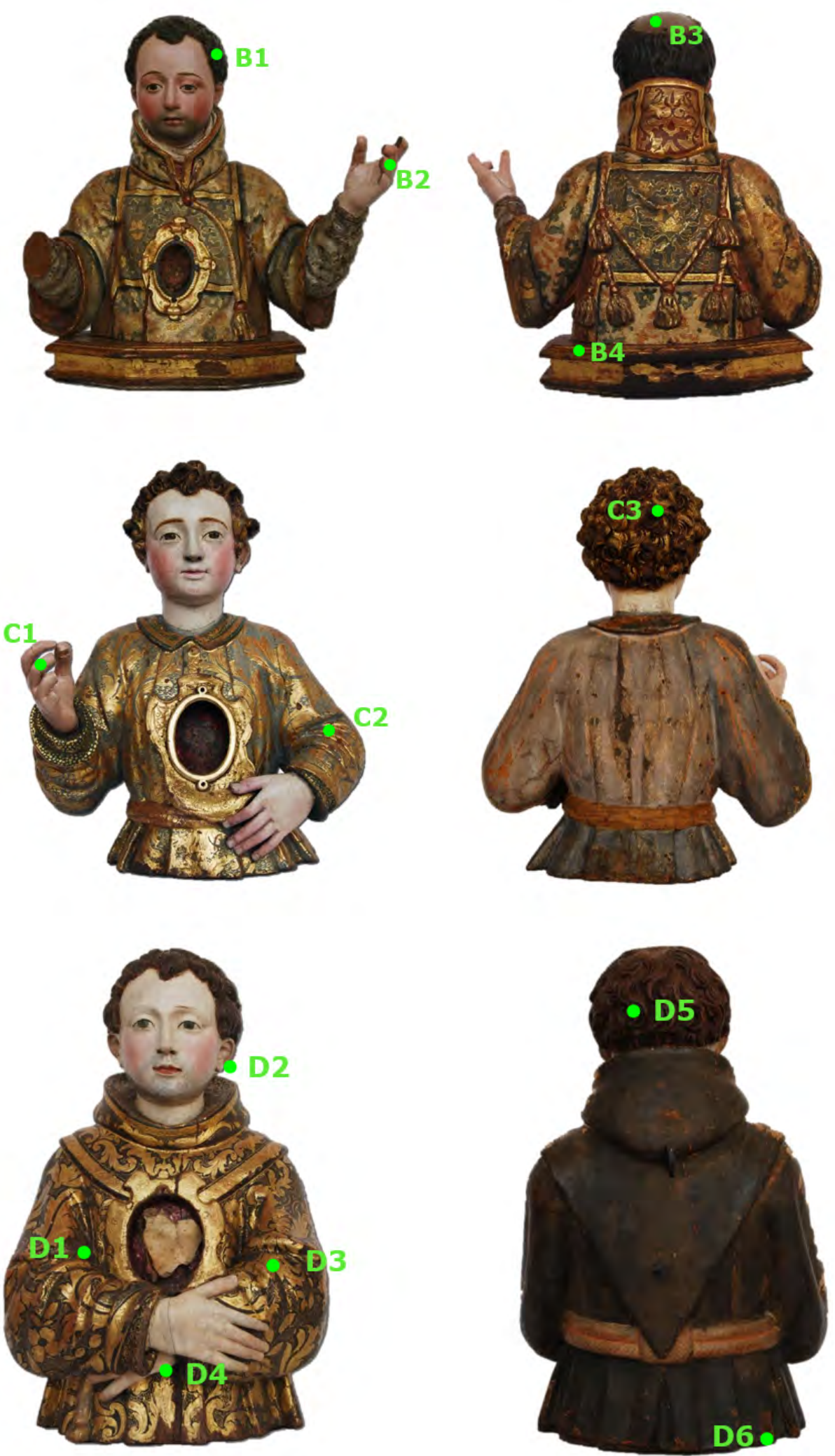

Figure 8 - Scheme from where samples were taken for the analytical study.

\section{Wooden Support}

Although no analysis, such as identification of the woody species or X-ray examinations for determining precisely the construction system, have been carried out to the wooden support, by naked eye observation it was possible to understand the constructive method of 
each sculpture. Three of the sculptures are composed of several wooden blocks (example in Figure 9) and one was sculpted from a single block.

Those blocks must have been united through iron nails, some of them visible at the surface.

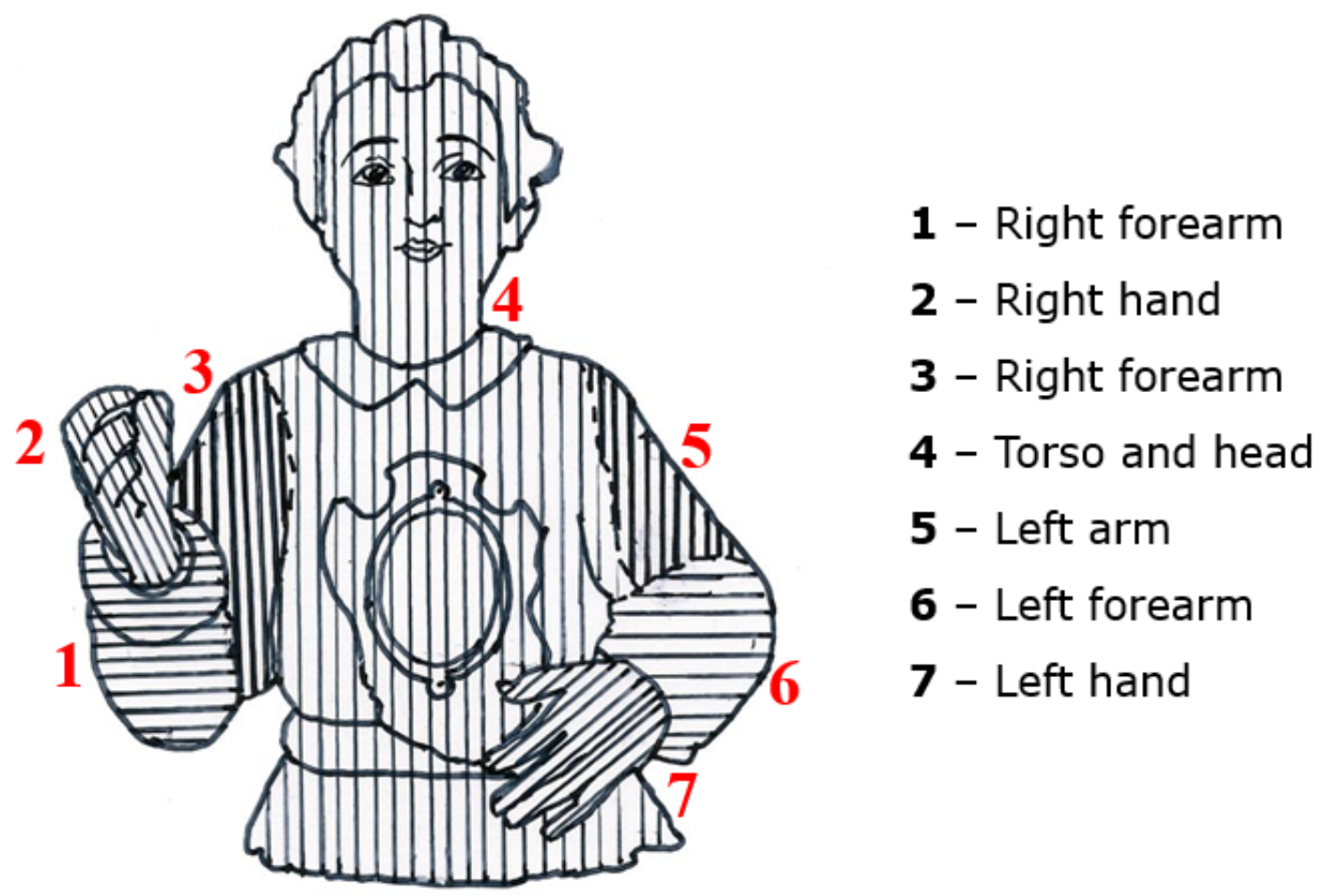

Figure 9 - Scheme of the block-building method (seven blocks) used for the bust of the Innocent Saint.

\section{Preparatory/Ground Layer}

The preparation layer of the four busts consists of calcium sulphate and animal glue. Observations under the optical microscope revealed layers of similar appearance in all busts, with a yellowish white hue. The natural colour of the gypsum is white and its browning may be associated with impurities such as iron oxides, silicates, calcium and magnesium carbonates, clay materials and small concentrations of other soluble salts (BARATA, 2015).

The detection of calcium (Ca) and sulphur (S) by SEM-EDS is what suggests the presence of calcium sulphate. However, the atomic ratios between $\mathrm{Ca}$ and $\mathrm{S}$, with values from 1.25 to 2.63 (Figure 10), suggest that calcium integrates the structure of others minerals, namely carbonates, besides being present in the form of sulphate (BARATA, 2015). 


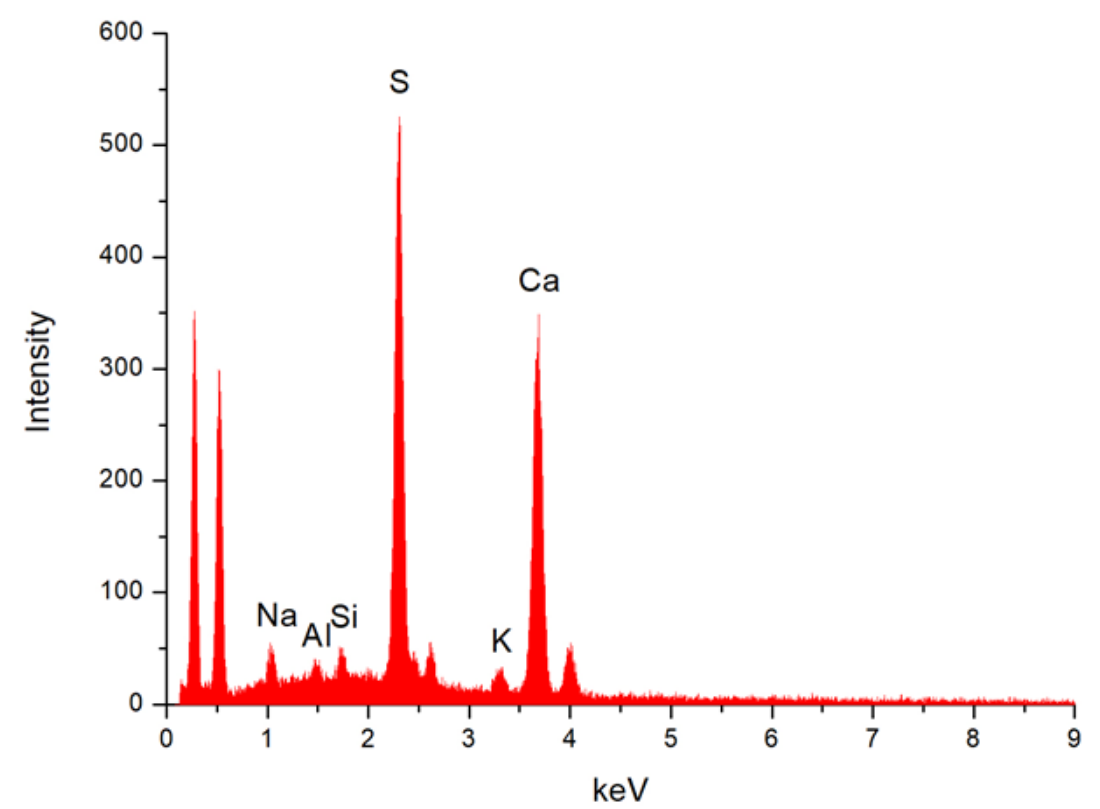

\begin{tabular}{|c|c|c|}
\hline Element & $\begin{array}{c}\text { Atomic concentration } \\
(\text { norm. wt. \%) }\end{array}$ & $\begin{array}{l}\text { Mass concentration } \\
(\text { norm. at. \%) }\end{array}$ \\
\hline $\mathrm{Ca}$ & 42,05 & 41,74 \\
\hline $\mathbf{S}$ & 26,9 & 33,33 \\
\hline Si & 2,25 & 3,19 \\
\hline $\mathbf{N a}$ & 2,12 & 3,67 \\
\hline $\mathbf{K}$ & 2,5 & 2,61 \\
\hline Al & 0,88 & 1,3 \\
\hline $\mathbf{Z n}$ & 23,25 & 14,15 \\
\hline Total & 100 & 100 \\
\hline $\begin{array}{c}\text { norm. at. } \% \\
\mathrm{Ca} / \mathrm{S}\end{array}$ & & 1,25 \\
\hline
\end{tabular}

\begin{tabular}{|l|l|l|}
\hline \multicolumn{1}{|c|}{ Element } & \multicolumn{1}{c|}{$\begin{array}{c}\text { Atomic concentration } \\
\text { (norm. wt. \%) }\end{array}$} & $\begin{array}{c}\text { Mass concentration } \\
\text { (norm. at. \%) }\end{array}$ \\
\hline $\mathbf{C a}$ & 69,21 & 63,50 \\
\hline $\mathbf{S}$ & 21,08 & 24,18 \\
\hline $\mathbf{S i}$ & 4,41 & 5,77 \\
\hline $\mathbf{N a}$ & 1,66 & 2,66 \\
\hline $\mathbf{K}$ & 2,56 & 2,41 \\
\hline Al & 1,08 & 1,48 \\
\hline Total norm. at.\% \\
$\mathbf{C a / S}$
\end{tabular}

Figure 10 - Representative EDS spectrum obtained for a ground layer from Saint Agatha's hair (sample A2) and tables with semi-quantitative analysis by EDS for the ground layers from Innocent Saint's vest (sample C2) and Saint Lawrence's flesh tone area (sample B2).

Aluminium (Al) and silicon ( $\mathrm{Si}$ ), corresponding to aluminosilicates and probably reflecting the presence of impurities, were also detected. 
Through $\mu$-FTIR, a protein glue was identified as the binding medium used for the ground layers (Figure 11). The fuchsine tests results suggest the use of the same material.

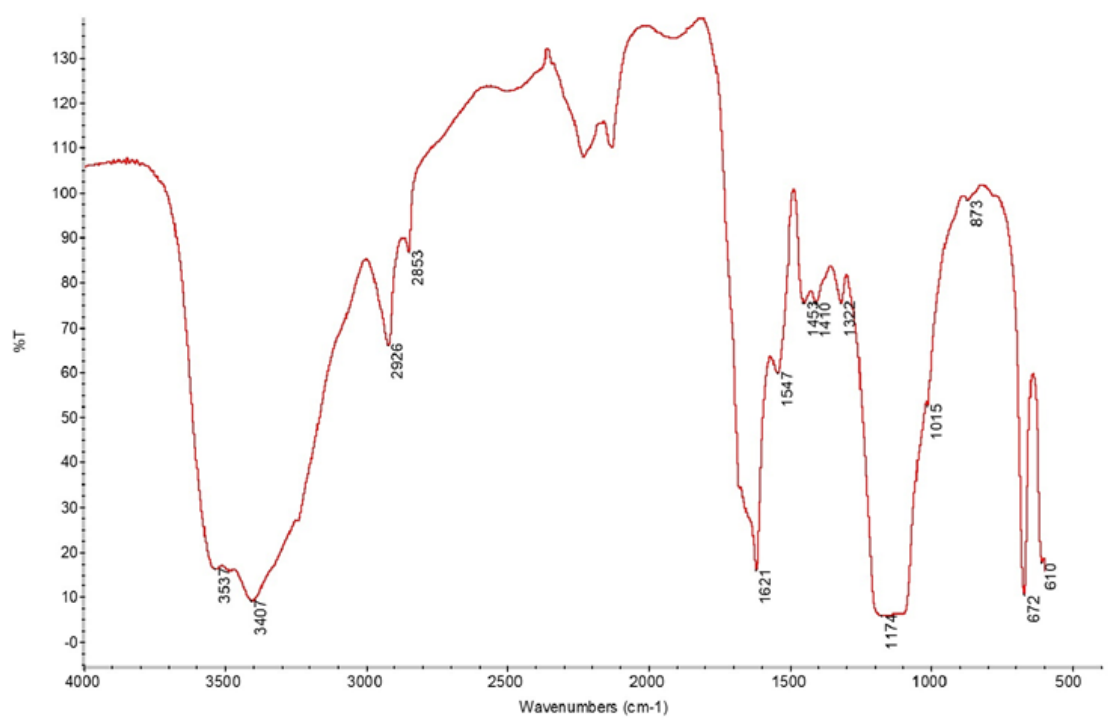

Figure 11 - $\mu$-FTIR spectrum obtained for the ground layer from Saint Agatha's pedestal (sample A3).

\section{Bole Layer}

Using the optical microscope in the samples collected from gilded areas it is possible to observe the bole layer, whose function is to provide a smooth and warm coloured surface adapted for the adhesion of the gold leaf. This layer arises immediately over the ground layer and two gilding techniques were distinguished: water gilding and oil gilding.

Samples collected from water gilding areas revealed a bole with tones of orange, red and yellow in thin and homogeneous layers. The EDS analysis of the samples collected from the water gilding areas suggest the presence of a bole composed of clay minerals rich in iron oxides ( $\mathrm{Al}$, Si e $\mathrm{Fe}$ ) and the $\mu$-FTIR results suggest the use of a protein medium as a binder (Figure 12).

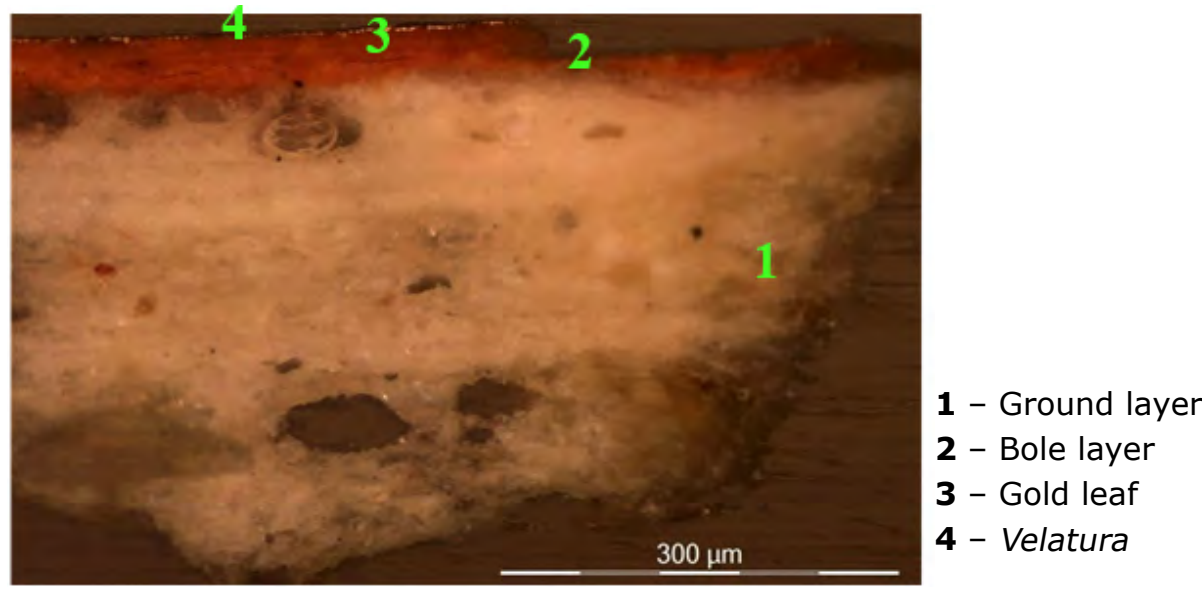




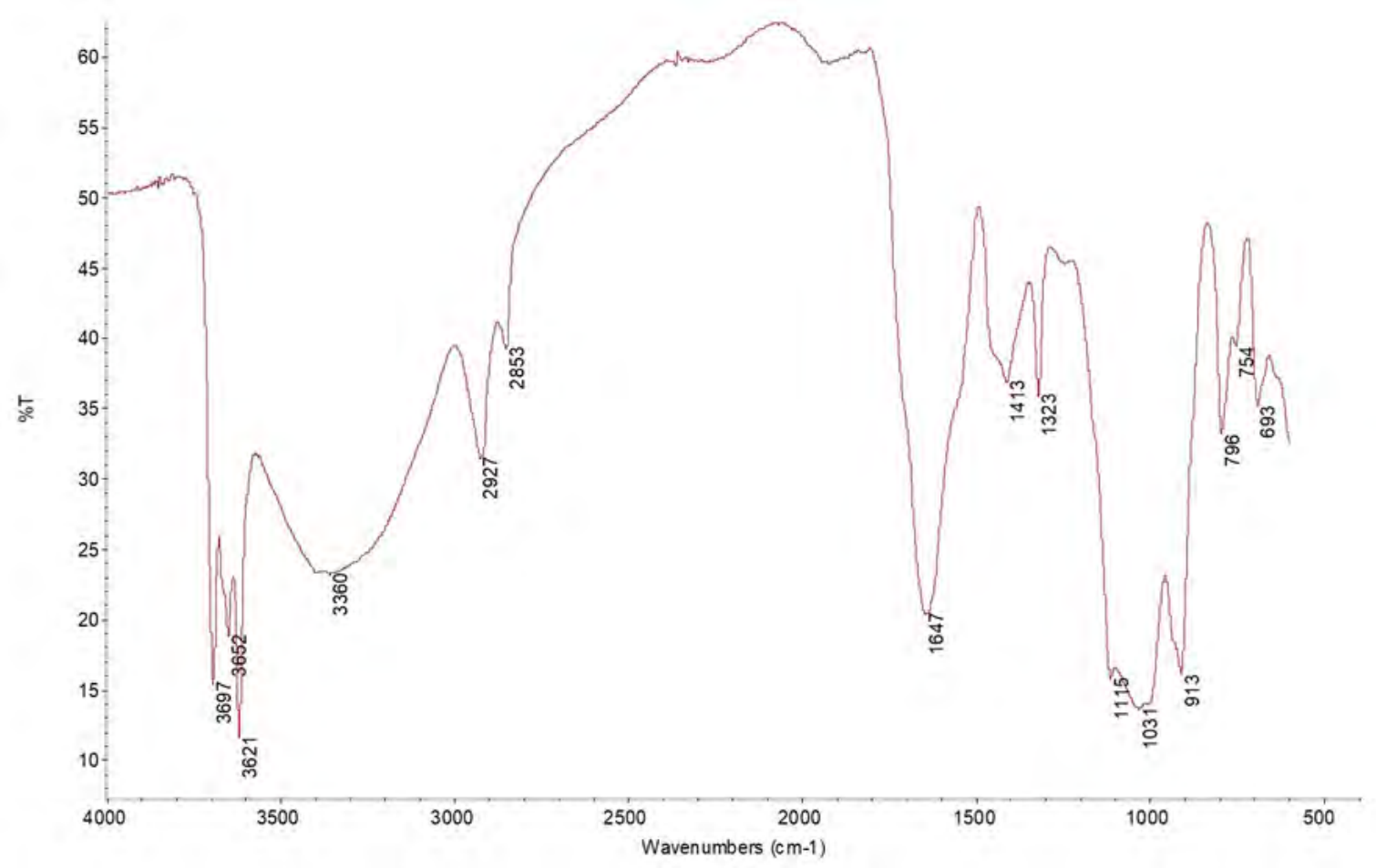

Figure 12 - Cross-section sample taken from a water gilding area (Saint Agatha's pedestal - sample A3) and a $\mu$-FTIR spectrum obtained for the layer 2 of sample A3.

The samples of oil gilding technique were collected from Saint Agatha and the Innocent Saint's hairs. Usually, these areas would not be composed of the traditional bole but rather from "a fat layer made of a drying-oil containing pigments rich in metallic oxides" (LE GAC et al., 2009). Observing the respective cross-sections with an optical microscope the samples revealed a layer with a brownish hue and translucent appearance, which suggests a mixture of pigments agglutinated in an oily medium. EDS analysis to one of the samples revealed significant concentrations of $\mathrm{Si}$ and lead $(\mathrm{Pb})$ which suggest a blend of earth and lead pigments (Figure 13).

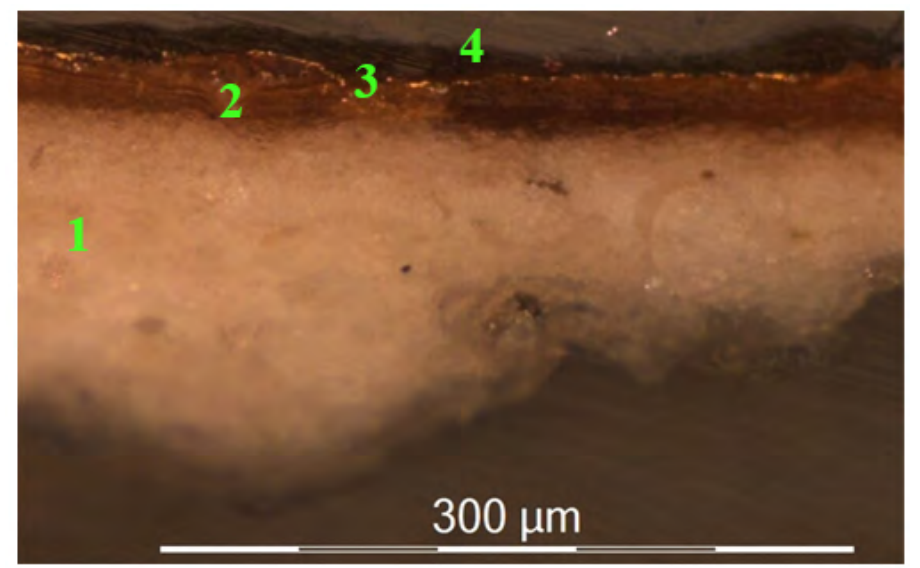

1 - Ground layer

2 - Bole layer

3 - Gold leaf

4 - Velatura 

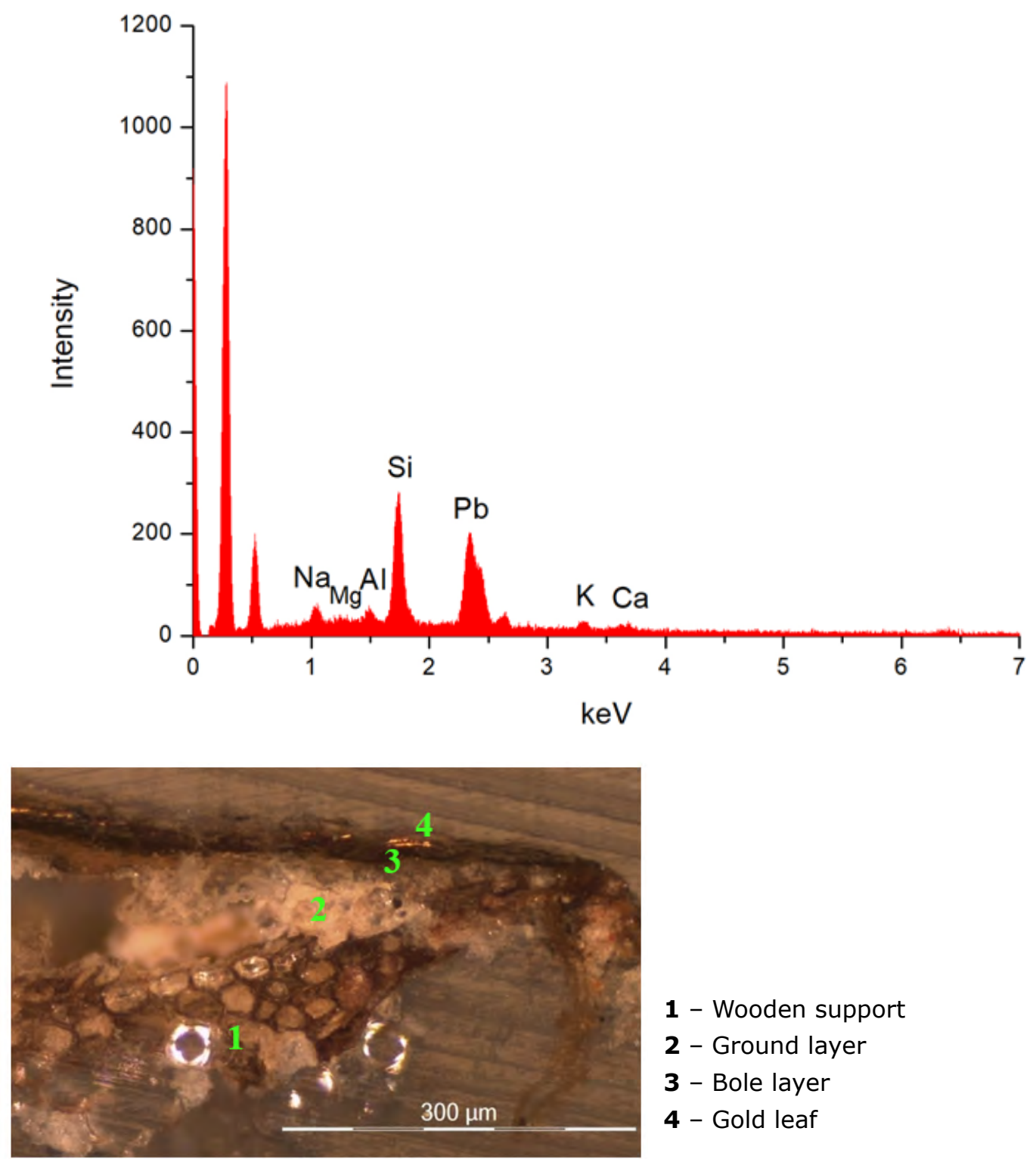

1 - Wooden support

2 - Ground layer

3 - Bole layer

4 - Gold leaf

Figure 13 - Cross-sections from oil gilding areas (Saint Agatha and Saint Innocent's hairs, respectively - samples $A 2$ and $C 3$ ) with a representative EDS spectrum from the layer 2 of Saint Agatha's hair (sample A2).

\section{Gold Leaf}

SEM-EDS was used to analyse the gold leaves and to characterize the metallic alloys through the acquisition of three-point spectra of the gold leaves. On average, they are composed of about $93 \%$ to $97 \%$ of gold $(\mathrm{Au}), 0,5 \%$ to $1 \%$ of copper $(\mathrm{Cu})$ and between $2 \%$ to $6 \%$ of silver (Ag) (Figure 13). The high Au content reveals high-quality gold leaves (between 22 and 23 carats), corresponding to the quality that would be most common at the time of execution (BARATA \& CRUZ \& ROCHA, 2011). This aspect confirms previous studies (BARATA, 2008, BARATA, 2015, SERCK-DEWAIDE et al., 2002, BIDARRA \& COROADO \& ROCHA, 2010, LE GAC et al., 2009) which suggest that the metal alloys used in Portugal would be, most likely, of high quality. 


\begin{tabular}{|l|l|l|l|l|}
\hline Wt. Norm. 100\% & Au & Cu & Ag & Carats \\
\hline & 93,5 & 0,8 & 5,76 & 22 \\
\hline
\end{tabular}

\section{Saint Lawrence}

\begin{tabular}{|l|l|l|l|l|}
\hline Wt. Norm. 100\% & Au & Cu & Ag & Carats \\
\hline & 97,3 & 0,46 & 2,01 & 23 \\
\hline
\end{tabular}

\section{Innocent Saint}

\begin{tabular}{|l|l|l|l|l|}
\hline Wt. Norm. 100\% & Au & Cu & Ag & Carats \\
\hline & 97,3 & 0,9 & 1,86 & 23 \\
\hline
\end{tabular}

\section{Franciscan Saint}

\begin{tabular}{|l|l|l|l|l|}
\hline Wt. Norm. 100\% & Au & Cu & Ag & Carats \\
\hline & 93,5 & 1,6 & 18 & 22 \\
\hline
\end{tabular}

Table 1 - Semi-quantification results of the gold leaves analysis regarding the average of the measurements made at three distinct points of the same layer.

One of the gold leaf analysed was collected from an oil gilding area and revealed an alloy with a lower carat value (22 carats). However, the studies conducted so far do not allow the association of a lower quality alloy to oil gilding areas, despite the fact that this suggestion was made in some studies (BARATA, 2015).

About the adhesives used in the gilding processes, despite no analysis were performed, they might be the same as those used in the bole layer (protein glue or oil) according to the gilding technique that was used (water or oil gilding, respectively).

\section{Estofado and Flesh Tone Layers}

The areas of flesh tones were obtained through pink strata applied directly over the ground layer, except for the bust of Saint Lawrence, in which the pink strata were applied over a white opaque layer, possibly of lead white ${ }^{2}$ (PACHECO, 2001, NUNES, 1982) (Figure 15).

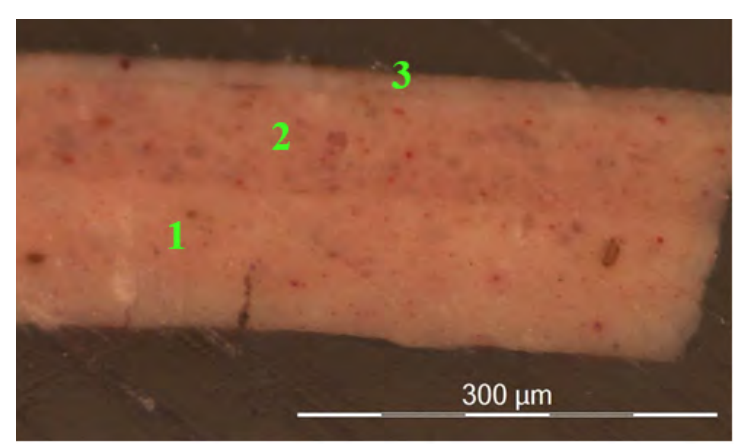

$\mathbf{1}$ - Flesh tone; $\mathbf{2}$ - Flesh tone; 3 - Flesh tone

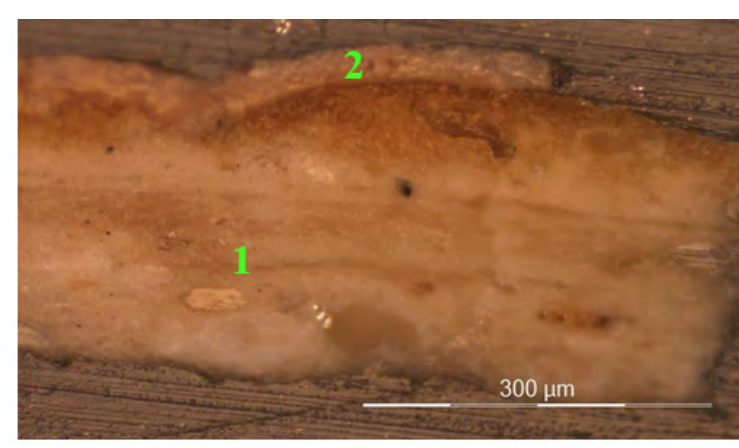

1 - Ground layer $\mathbf{2}$ - Flesh tone

\footnotetext{
${ }^{2}$ Sometimes it would be frequent the application of an intermediate white layer, composed of white lead, between the ground and the remaining polychrome layers.
} 


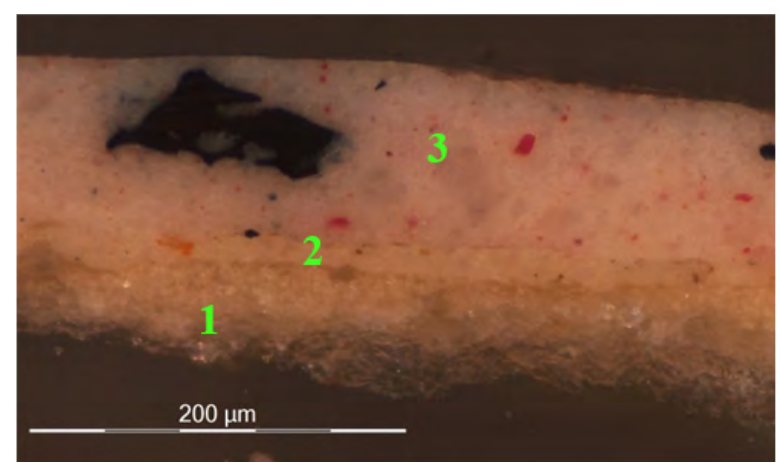

1 - Ground layer $\mathbf{2}$ - White opaque layer 3 - Flesh tone

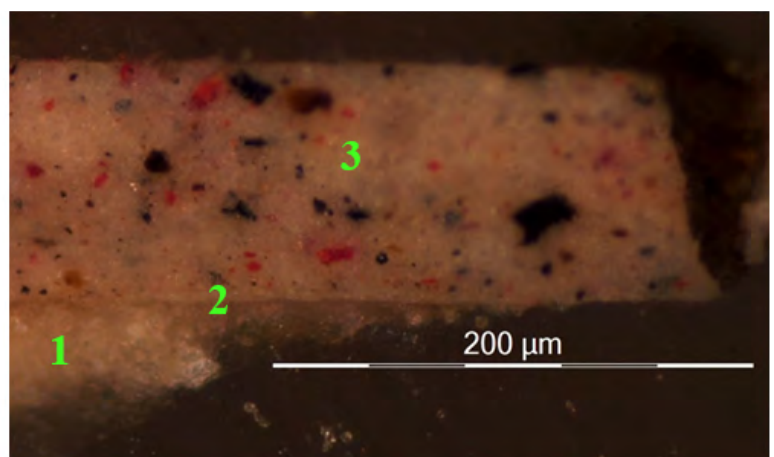

1 - Ground layer $\mathbf{2}$ - White opaque layer 3 - Flesh tone

Figure 14 - Cross-sections from flesh tones areas corresponding to Innocent Saint (sample C1), Saint Agatha (sample A1), and Saint Lawrence (samples B2 and B3), respectively.

The analytical results suggest that the areas of flesh tones have been executed according to the art treatises of the time (NUNES, 1982, PACHECO, 2001). Moreover, it is possible to divide the busts into groups of two according to the materials used in their construction: by SEM-EDS, Pb was detected in the bust of Saint Agatha and Saint Lawrence and, according to $\mu$-FTIR analysis, the lead compound corresponds to white lead (Figure 15). This lead compound could also be related to the use of minium, which cannot be detected through $\mu$-FTIR. In the bust of the Innocent Saint and the Franciscan Saint, the EDS results also suggest the use of lead white and the detection of mercury $(\mathrm{Hg})$ indicates the use of vermillion (Figure 16).
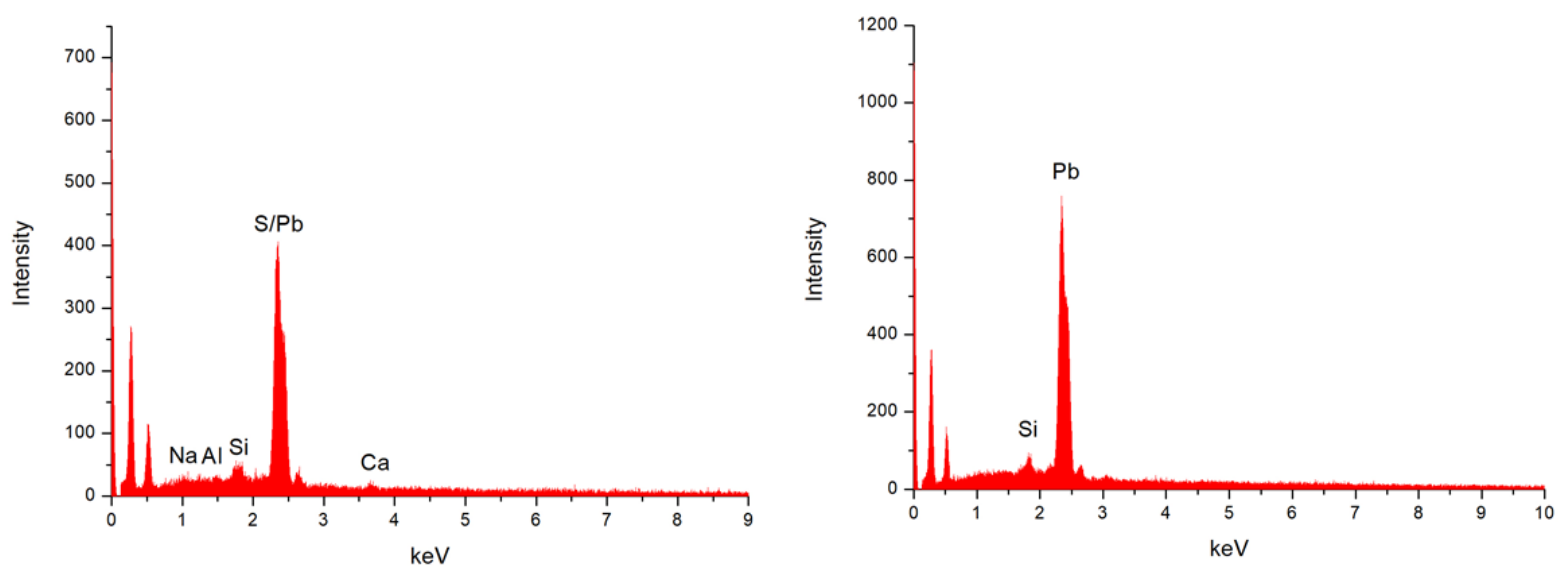


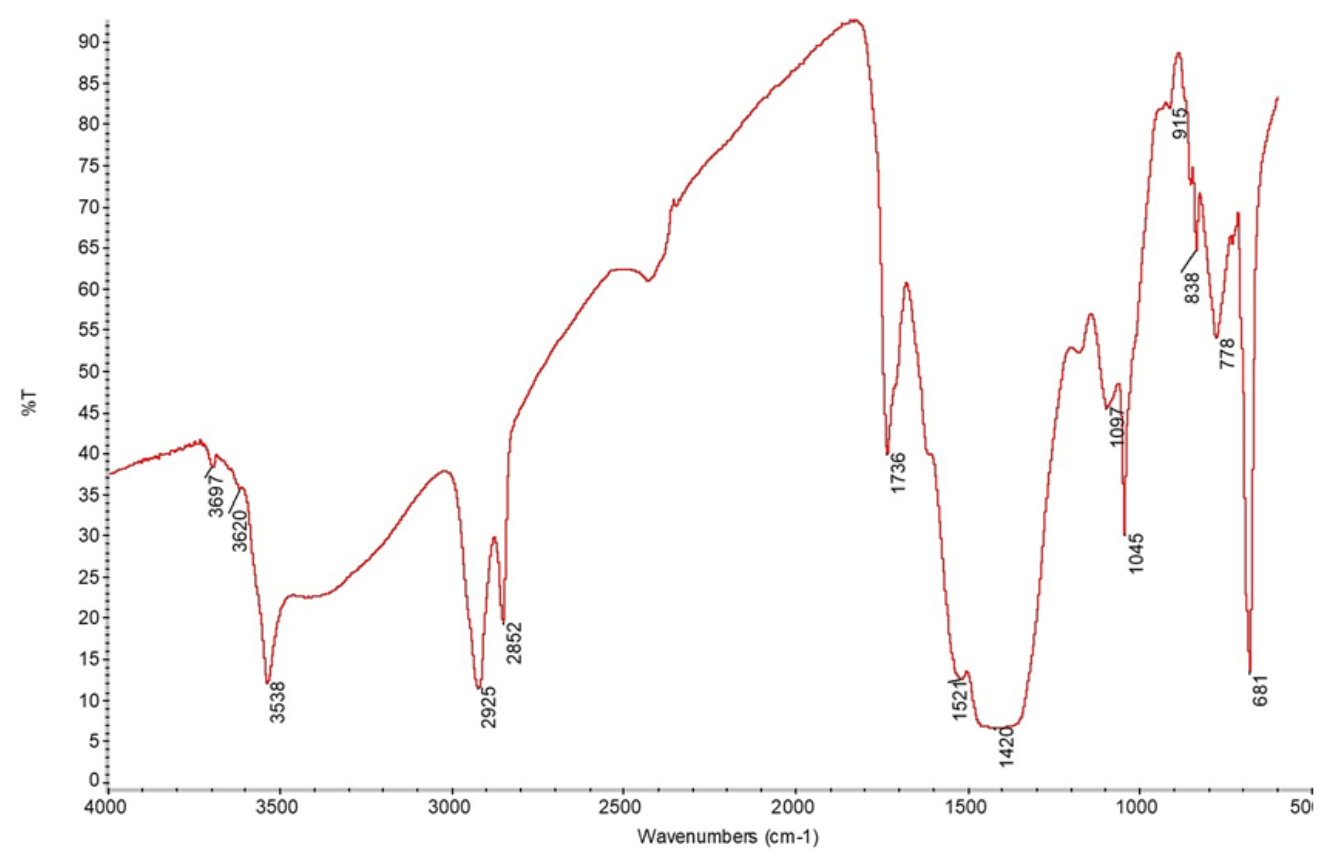

Figure 15 - Representative EDS spectra obtained for the layers $\mathbf{2}$ and $\mathbf{3}$ from Saint Agatha and Saint Lawrence's flesh tones area (samples A1 and B2), respectively, and a $\mu$-FTIR spectrum obtained for the layer $\mathbf{3}$ from Saint Lawrence flesh tones area (sample B3), where it was identified cerussite and hydrocerussite (white lead pigment).
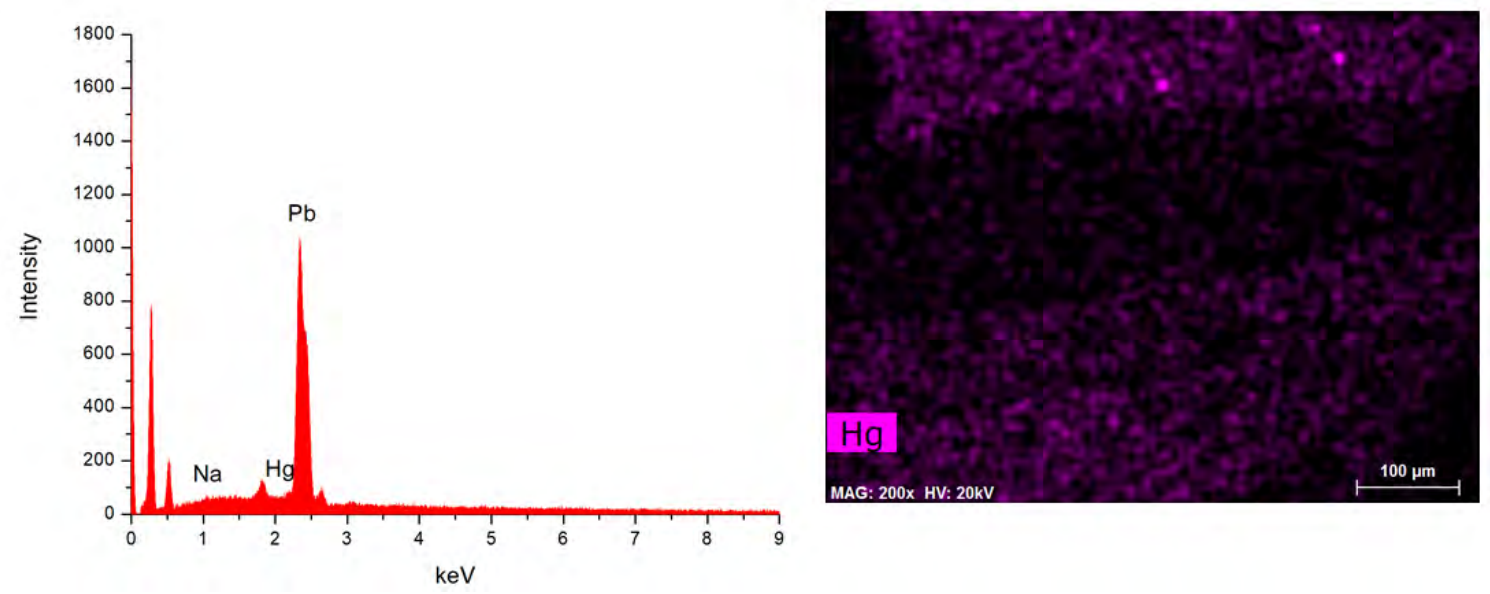

Figure 16 - Representative EDS spectrum obtained for the layer $\mathbf{3}$ from Innocent Saint's flesh tones area (sample $\mathrm{C} 1$ ) and an SEM-EDS map of elemental distribution $(\mathrm{Hg})$ for the Franciscan Saint's flesh tones area (sample D4).

In the estofado garments, only those of the Innocent Saint and the Franciscan Saint were analysed. In the Innocent Saint blue tunic, white lead was identified through SEM-EDS and $\mu$-FTIR. The detection of copper carboxylates by $\mu$-FTIR suggests the use of a blue pigment composed of copper, such as azurite or indigo. The detection of $\mathrm{Al}, \mathrm{Si}$, and $\mathrm{Fe}$ in the Franciscan Saint brown vest, by SEM-EDS, suggests the use of earth pigments (Figure 17). 


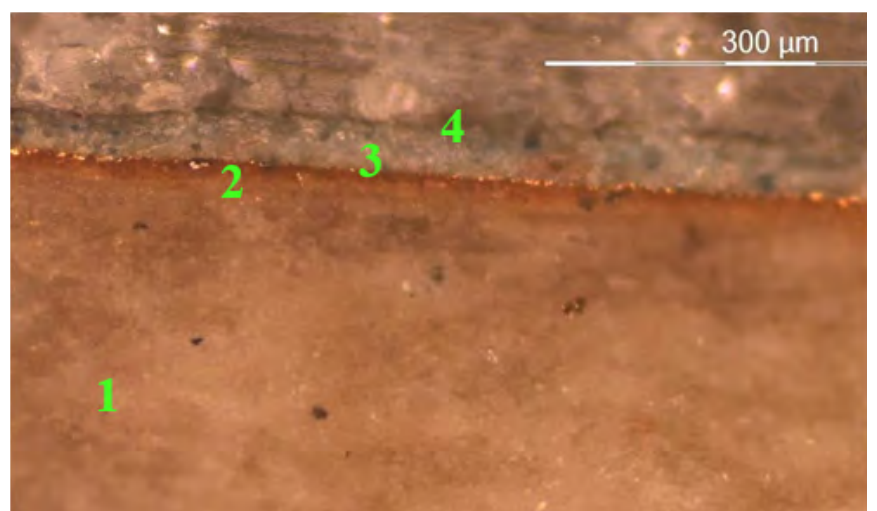

1 - Ground layer

2 - Bole layer

3 - Gold leaf

4 - Blue layer
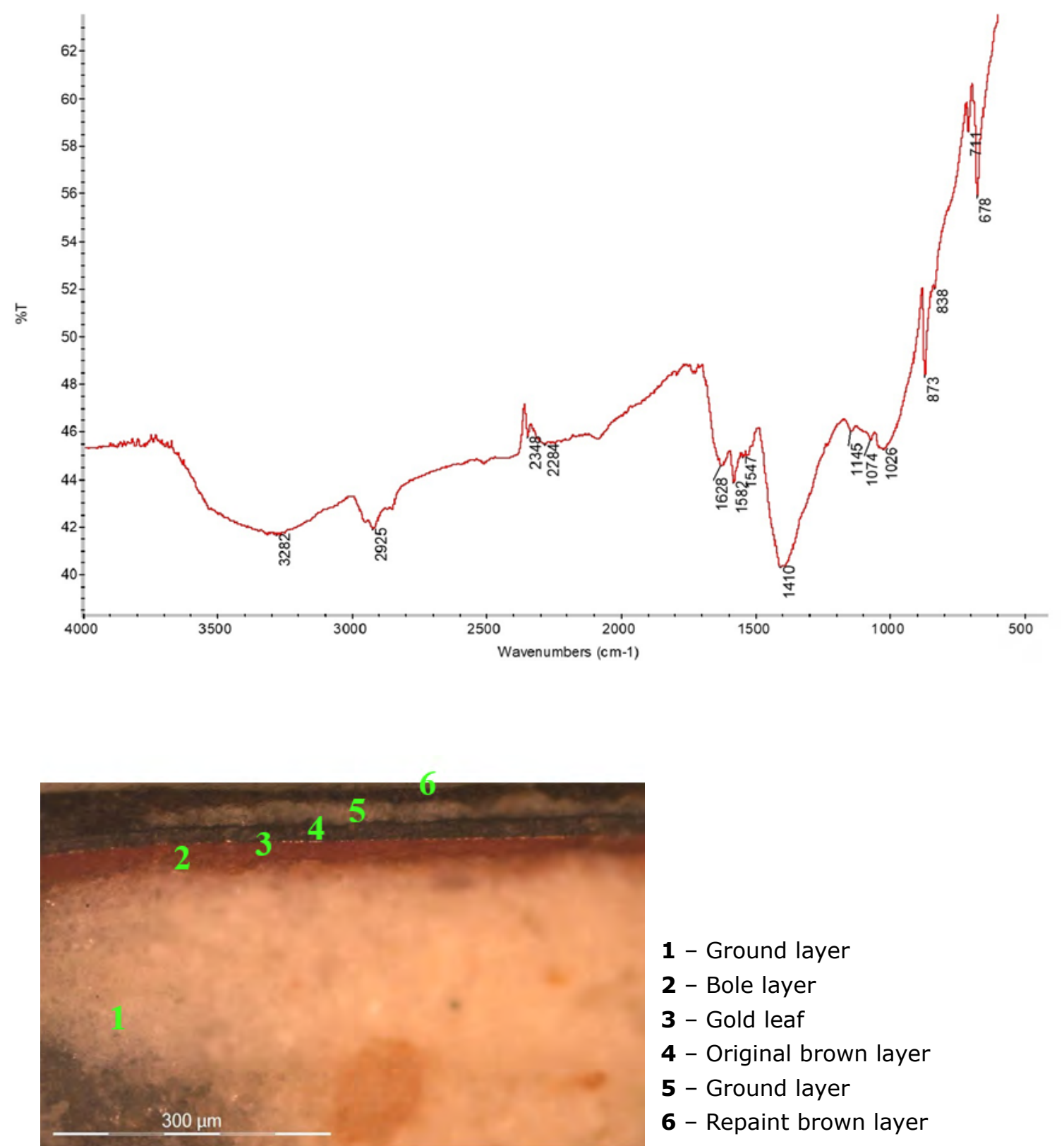

1 - Ground layer

2 - Bole layer

3 - Gold leaf

4 - Original brown layer

5 - Ground layer

6 - Repaint brown layer 


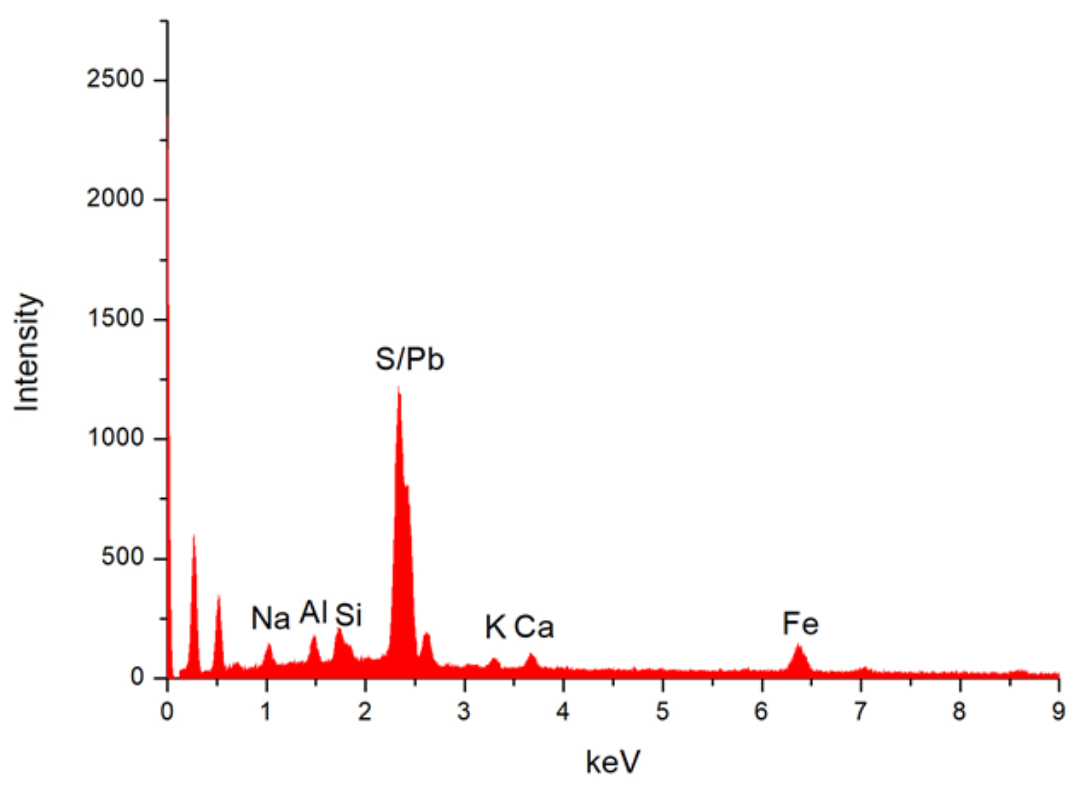

Figure 17 - Cross-sections from estofado areas (Innocent Saint and Franciscan Saint, respectively - samples C1 and D6) with the $\mu$-FTIR spectra obtained for the layer 4 from Innocent Saint's blue vest (sample C2) and a representative EDS spectrum obtained for the layer $\mathbf{4}$ of Franciscan Saint's brown vest (sample D6).

\section{Later Interventions}

Through the observation of the cross-sections by optical microscopy it was possible to identify the presence of repaintings applied in some areas of the Innocent Saint and Franciscan Saint's busts. In Innocent Saint's bust, the repaintings applied on a flesh area probably did not cause a great alteration of the original aspect as the chromatic layers are similar to the original one (see Figure 14).

In the Franciscan Saint's bust some differences are noticeable in gilding and flesh tone areas: using the optical microscopy it is visible, in gilding areas, that the second bole layers have a different colour and texture from the original one; in a flesh tone area, the SEM-EDS analysis revealed a different composition in the ground layer (calcium carbonate), since no $\mathrm{S}$ was detected, but the same red pigment in the chromatic layer (vermillion) (Figure 18).

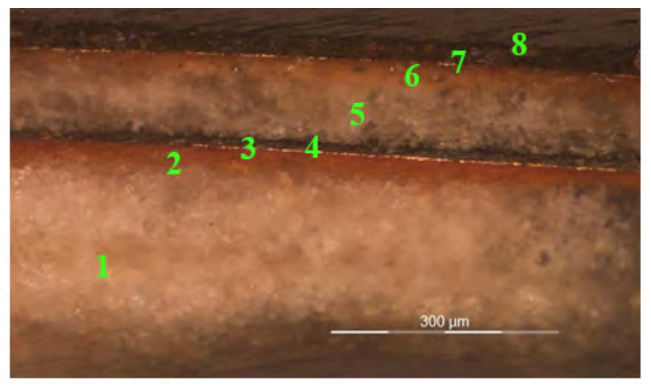

$$
\begin{aligned}
& \mathbf{1} \text { - Ground layer } \\
& \mathbf{2} \text { - Bole layer } \\
& \mathbf{3} \text { - Gold leaf } \\
& \mathbf{4} \text { - Original brown layer } \\
& \mathbf{5} \text { - Ground layer } \\
& \mathbf{6} \text { - Bole layer } \\
& \mathbf{7} \text { - Gold leaf } \\
& \mathbf{8} \text { - Repaint brown layer }
\end{aligned}
$$



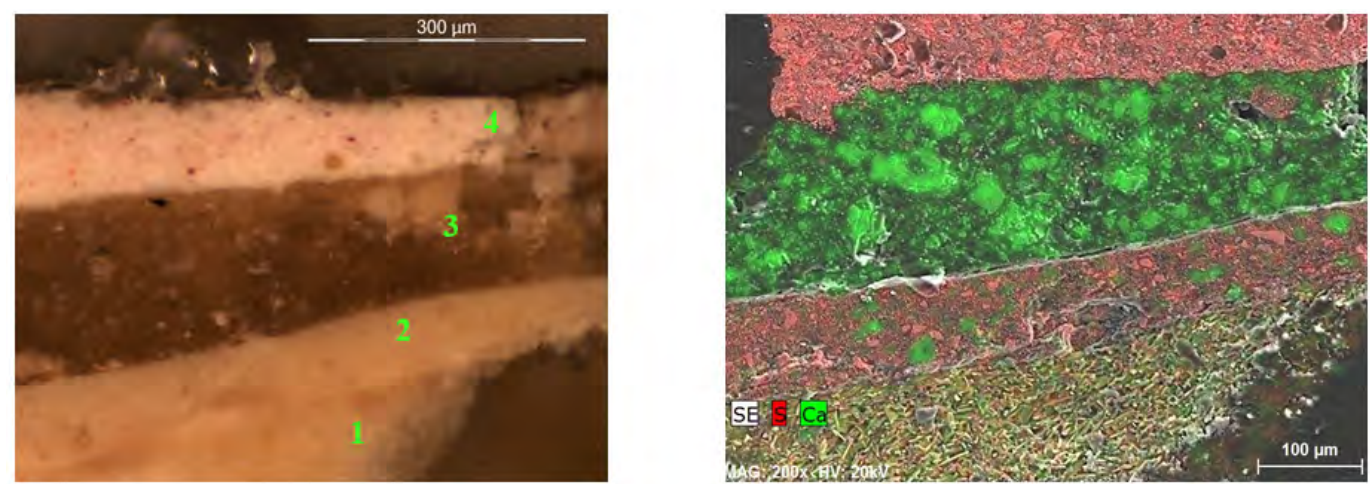

1 - Ground layer

2 - Flesh tone

3 - Ground layer

4 - Repaint flesh tone

Figure 18 - Cross-sections from Franciscan Saint's estofado (sample D3) and flesh tone area (sample D4) with an SEM-EDS map of elemental distribution for the flesh tones area (sample D4).

\section{Conclusion}

This project allowed to initiate the historical, artistic, technical and material study of the set of reliquary busts from the Monastery of Madre de Deus in Lisbon.

The sculptures in this study seem to fit the artistic production of the early $17^{\text {th }}$ century, with mannerists features, such as the idealized beauty of Saint Agatha and Saint Lawrence, which contrast with the natural baroque faces of the Innocent and Franciscan Saints.

Regarding the construction method, the use of several wooden blocks shows good technical execution, unlike the bust of Franciscan Saint which, for having been executed on a single block, suffered a large vertical slit.

The results of the analytical study suggest that the materials and techniques correspond to the practices in use during the $17^{\text {th }}$ century. The surfaces of all busts are coated with a ground layer composed of gypsum and a protein binder; in the flesh and brown hair areas the chromatic layers were applied directly over the ground layer, except for the bust of Saint Lawrence in which it was detected an intermediate layer of white lead; in the estofado and gilded hair areas it was applied a bole layer over the ground layer, which function is to prepare the surface to receive the gold leaves, which in these sculptures are of high quality; in the water gilding areas, the bole is composed of the traditional iron oxides rich clay material, and in oil gilding areas it is composed of a blend of earth and lead pigments; for the flesh tone areas it was used white lead and minium or white lead and vermillion, it was used earth pigments for the brown vests and azurite or indigo in a matrix of white lead for the blue ones; in some samples repaintings were detected, something that should correspond to old restoration treatments.

Considering the conservation condition of these sculptures, they probably have been exposed to oscillations of relative humidity and temperature which led to the wooden support's cracking and detachment of the polychrome coating. Those factors led to a need for conservation treatments which respected the aesthetic singularity of the four reliquary busts. 
Although the studied sculptures are currently in the storage area of the National Azulejo Museum, the intended propose of this institution is to place the reliquaries in their original location, the high choir of the church, which is still open to worship.

Given the lack of specific literature on the reliquary bust typology in Portugal, and in particular on those of Madre de Deus, it will be pertinent to proceed and develop this study in order to enhance knowledge on the materials and techniques used in the production of these sculptures, on the relics they contain, and to complete an iconographic study of the set. This will allow the National Azulejo Museum to reconstitute the reliquary cabinet in an organized way by themes and invocations.

\section{References}

BARATA, Carolina. Caracterização de materiais e de técnicas de policromia da escultura portuguesa sobre madeira de produção erudita e de produção popular da época barroca. Lisboa: Dissertação de Mestrado em Química Aplicada ao Património Cultural apresentada na Faculdade de Ciências da Universidade de Lisboa, 2008.

BARATA, Carolina; CRUZ, António João; ROCHA, Fernando Tavares. Sobre os materiais utilizados na talha da época barroca do Noroeste de Portugal - primeiros resultados. In I ENCONTRO LUSO-BRASILEIRO DE CONSERVAÇÃO E RESTAURO: actas. Porto: CITAR, 2011, pp. $40-50$.

BARATA, Carolina. Materiais e técnicas de policromia da talha barroca erudita e popular no Noroeste de Portugal. Aveiro: Dissertação de Doutoramento em Geociências apresentada na Universidade de Aveiro, 2015.

BIDARRA, Ana; COROADO, João; ROCHA, Fernando. Contributos para o estudo da folha de ouro de retábulos barrocos por microscopia óptica e electrónica. In Ge-conservación/ conservação, Vol 1 (2010), pp. 183 - 191.

BRANDI, Cesare. Teoria do Restauro. Amadora: Edições Orion, 2006.

BRITO, Maria Filomena; MORNA, Teresa Freitas. Escultura: Colecção de escultura da Misericórdia de Lisboa: Século XVI ao século XX. Lisboa: Santa Casa da Misericórida, 2000.

CALVO, Ana. Conservación y restauración: materiales, técnicas y procedimientos: De la A a la Z. Barcelona: Ediciones del Serbal, 1997.

CURVELO, Alexandra (Ed.). Casa perfeitíssima: 500 anos da fundação do Mosteiro da Madre de Deus - Celebrating 500 years of the foundation of the Monastery of Madre de Deus: 1509-2009. Lisboa: IMC, Museu Nacional do Azulejo, 2009.

DIAS, Pedro. A importação de esculturas de Itália nos séculos XV e XVI. Coimbra: Livraria Minerva, 1987.

DIAS, Pedro. A escultura maneirista portuguesa: Subsídios para uma síntese. Coimbra: Minerva Editora, 1995.

DÍAZ MARTÍNEZ, Soledad; GARCÍA ALONSO, Emma. Técnicas metodológicas aplicadas a la conservación-restauración del patrimonio metálico. Madrid: Ministério da Cultura, 2011. 
LE GAC, Agnès; [et al.]. The main altarpiece of the Old Cathedral of Coimbra (Portugal), Characterization of gold alloys used for gilding from 1500 to 1900. In ArchéoSciences, Vol 33 (2009), pp. $423-432$.

NUNES, Filipe. Arte da pintura: symmetria e perpectiva. Composta por Philippe Nunes, com um estudo introdutório de Leontina Ventura. Porto: Editorial Paisagem, 1982.

PACHECO, Francisco. El arte da la pintura. Madrid: Ediciones Cátedra, 2001.

PEREIRA, Helena. «Saint John at Calvary: technical and material study of a polychrome wood sculpture». In CeROArt. 2013. [Consult: 21.02.2017]. https://ceroart.revues.org/3197.

SERCK-DEWAIDE, Myriam; [et al.]. Les techniques utilisées dans l'art baroque religieux des XVIIe et XVIIIe siècles au Portugal, en Espagne et en Belgique. In Actas do Congresso Internacional - A escultura polícromada religiosa dos séculos XVII e XVIII: estudo comparativo das técnicas, alterações e conservação em Portugal, Espanha e Bélgica. Lisboa: Instituto Português de Conservação e Restauro, 2002, pp. 119 - 155.

TELLES, Liberato. Mosteiro e egreja da Madre de Deus. Lisboa: Imprensa Moderna, 1899. VICENTE RABANAQUE, Teresa (2015). Los criterios en conservación y restauración del siglo XX, en el contexto mediterráneo, a las puertas del nuevo siglo. In Tarea. 2015, [Consult: 15.11.2016]. http://webcache.googleusercontent.com/search?q=cache:fYSUffExwes]:www.unsam.edu.ar/ojs/index.php/tarea/article/download/63/55+\&cd =1\&hl=pt-PT\&ct $=-$ clnk\&gl=pt.

VIVANCOS RAMÓN, Victoria; PÉREZ MARIN, Eva. Revisión crítica de los diferentes sistemas de desinfección aplicados a la retablística barroca. In XIV CONGRESSO DE CONSERVACIÓN Y RESTAURACIÓN DE BIENES CULTURALES: actas. Valladolid: Ayuntamiento de Valladolid, 2002, pp. $68-73$.

VIVANCOS RAMÓN, Victoria. La conservación y restauración de pintura de caballete: pintura sobre tabla. Madrid: Editorial Tecnos, 2007.

\section{Ackowledgments}

Authors thank to Nacional Azulejo Museum, HERCULES Laboratory of the University of Évora and to the Research Center of Geobiosciences, Geotechnologies and Geoengineering (GeoBioTec) of the University of Aveiro, which supported this study.

\section{Author's Curriculum Vitae}

\section{Diana Cunha}

Holds a degree in Conservation and Restoration by the School of Arts of the Portuguese Catholic University (EA/UCP) and completed her Master's degree in Conservation and Restoration of Cultural Heritage with specialization in sculpture and carving, at the same institution. During her academic path, she participated in several conservation works, either in the context of classes or in volunteerism during the summer campaigns annually organized by EA/UCP.

Contact: diana.tscunha@gmail.com 


\section{Carolina Barata}

Holds a degree in Conservation and Restoration, a post-graduation in Art Expertise, a Master's degree in Applied Chemistry and a PhD in Geosciences. She started her professional activity in 1996 having joined several working teams in the field of Easel Painting, wooden Sculpture and carved wood Conservation. Since 2005 she joined the School of Arts of the Portuguese Catholic University (EA/UCP) as a lecturer and a researcher. Since 2016 she coordinates the Master's Degree in Conservation and Restoration in the same School. She is a member of the Research Center for Science and Technology of the Arts (CITAR) at EA/ UCP and of the Research Center of Geobiosciences, Geotechnologies and Geoengineering (GeoBioTec) of the University of Aveiro.

Contact: cbarata@porto.ucp.pt

\section{Alexandre Pais}

Researcher at the Nacional Azulejo Museum, from 1993 to 2004 and again since 2009. He has also worked at the Pena Palace, Sintra (1987-1993) and at the Portuguese Institute for Conservation and Restoration, previous José de Figueiredo Institute (2004-2009). He has lectured at the Superior School of Decorative Arts at the Ricardo do Espírito Santo Silva Foundation, Portuguese Catholic University (UCP) and School of Conservation and Restoration, Sintra. He has published various articles and books on artistic heritage, mainly on Portuguese tiles and ceramics, and he is a member of several research groups. He has a $\mathrm{PhD}$ in Decorative Arts from the UCP, dedicated to the production of Portuguese faience from c. 1550-1750, under the supervision of Prof. Dr Gonçalo de Vasconcelos e Sousa.

Contact: apais@mnazulejo.dgpc.pt 